\section{Committee looks into the future of US space science}

Washington. A newly formed panel of the US National Research Council (NRC) begins work this month to recommend a new course for space science in an era of shrinking budgets, increased cooperation and greater demand that research be tied to economic goals.

The Future of Space Science panel, chaired by John Armstrong, former head of research at IBM, will also consider the possibility of creating a new national institute of space science within the National Aeronautics and Space Administration (NASA), modelled loosely on the National Institutes of Health (NIH).

The Senate subcommittee that decides NASA's budget ordered the study last September in the wake of the agency's decision to divide its office of space science into three smaller offices responsible for Earth sciences, life and microgravity sciences, and astronomy and planetary exploration.

The subcommittee felt that this new structure would make it difficult for NASA to establish cross-disciplinary priorities, and for Congress to monitor its activities. It was also "deeply troubled" by the lack of plans (meaning money) for new space science missions after 1997, something the new NRC panel will also be looking at.

According to NASA's chief scientist, France Cordova, the agency already has a plan to address this problem. If its science managers can cut $\$ 100$ million from their overall operational budget, they will receive a funding 'wedge' of up to US\$300 million for new science missions. The money would be trimmed from other NASA programmes. The incentive is working, according to Cordova, who says that managers of the Cassini Saturn mission have already identified "pretty dramatic proposed savings" in their operations budget.

The problems go beyond just money, however. In fact, NASA's space science budget is bigger than the entire annual budget of the National Science Foundation. But the money is not always well spent, according to another recently published NRC report. Entitled A Space Physics Paradox, the report has the intriguing subtitle, "Why has increased funding been accompanied by decreased effectiveness in the conduct of space physics research?"

The report's authors found that "factors such as planning, marketing, the funding process, and project management have become as responsible for the increased delays, costs, and frustration levels in space physics as technical complications relating to increasing project size and complexity". They recommend that the balance of funding be shifted toward smaller programmes,

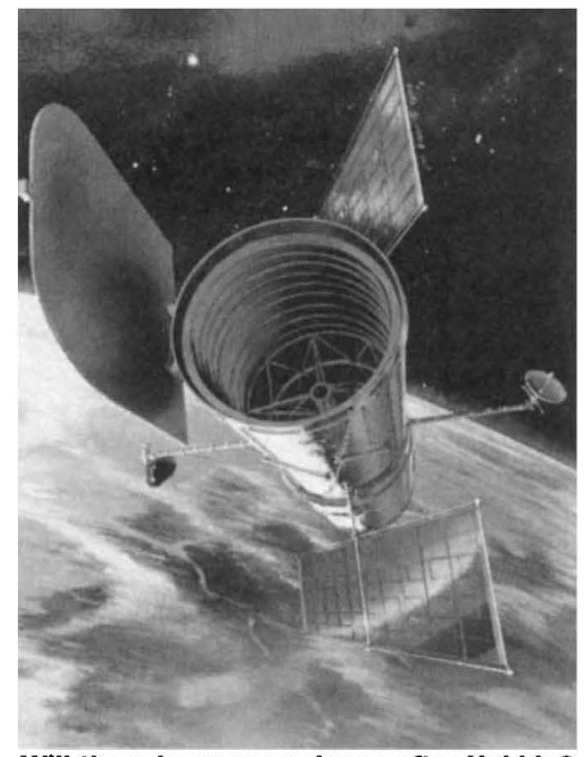

Will there be space science after Hubble?

even if it means reducing the number of large programmes. And although they looked at only one discipline - space physics the report's authors believe "the subject and results of this study apply to many other areas of science as well"

Another difficulty facing space science is that its role in the US space programme is not well defined. "We have not established an overall space policy for the country," says Louis Lanzerotti of AT\&T's Bell Laboratories, who until recently chaired the Space Studies Board. The last attempt to define such a policy — the 1990 report by the presidentially commissioned Augustine Committee — recommended that science should be NASA's top priority. That advice was largely ignored as the White House and the space agency concentrated instead on getting the space station approved.

NASA is often accused of over-emphasizing human flight to the detriment of science. But although shuttle and space station managers do sometimes treat science as an afterthought - the NRC's Space Studies Board wrote to Daniel Goldin, administrator of NASA, last month to complain that Spacelab science experiments were being bumped to make room for logistics payloads - space science and the human space programme are more often symbiotic. The shuttle and space station need onboard research to justify their existence. And without those projects to draw political, industrial and public support, funding for the rest of NASA's space science activities would almost certainly dwindle. The new NRC panel will have to take that reality into account as it tries to chart the future of space science.

Tony Reichhardt

\section{New president for South Korea's university of steel}

Tokyo. One of South Korea's newest universities, the Pohang University of Science and Technology (POSTECH), last week appointed a US-trained Korean engineer as its new president following the sudden death of POSTECH's first president, Hogil Kim, in a sporting accident earlier this year.

POSTECH is unusual in that it receives a substantial part of its funds from one of the world's most profitable steel manufacturers, the Pohang Iron and Steel Company (POSCO) (see Nature 364, 380; 1993). Now ranked as one of South Korea's leading universities, POSTECH was established with POSCO's support on a plush new campus in 1987. The company provides about 60 per cent of the university's annual research funds of about US $\$ 28$ million via an adjacent company research institute, the Research Institute of Science and Technology.

POSTECH has recruited nearly all its faculty from top universities and research organizations in the United States. The new president, Sooyoung Chang, is no exception. Chang received his $\mathrm{PhD}$ from the University of Maryland in 1971 and taught at the State University of New York before working as a systems engineer in private companies in the United States.

David Swinbanks

\section{Japan's H-II rocket fizzles on launch pad}

Tokyo. Officials of Japan's National Space Development Agency (NASDA), who hope to compete in the world market for the commercial launch of satellites, were embarrassed last week when their new $\mathrm{H}$-II rocket failed to get off the launch pad in its first mission.

The H-II, which was successfully testlaunched for the first time earlier this year (see Nature 367, 500; 1994), fired its main liquid fuel engine six seconds before lift off, but then solid fuel boosters failed to ignite and the launch was aborted. The rocket was intended to place a two-tonne test communications satellite into geostationary orbit.

NASDA has traced the problem to a faulty computer chip in ground-based launch control equipment. The $\mathrm{H}-\mathrm{II}$ is much more expensive than competing commercial launch vehicles like Europe's Ariane rockets and NASDA officials have been emphasizing the reliability of their technology, rather than price. But last Thursday's failure came on top of an earlier launch cancellation due to a faulty valve. A third attempt to launch the rocket will be made on Sunday (28 August).

David Swinbanks 